\title{
Stiffness and Damping Coefficient Estimation of Compliant Surface Gas Bearings for Oil-Free Turbomachinery
}

Christopher DellaCorte

Glenn Research Center, Cleveland, Ohio 


\section{NASA STI Program . . . in Profile}

Since its founding, NASA has been dedicated to the advancement of aeronautics and space science. The NASA Scientific and Technical Information (STI) program plays a key part in helping NASA maintain this important role.

The NASA STI Program operates under the auspices of the Agency Chief Information Officer. It collects, organizes, provides for archiving, and disseminates NASA's STI. The NASA STI program provides access to the NASA Aeronautics and Space Database and its public interface, the NASA Technical Reports Server, thus providing one of the largest collections of aeronautical and space science STI in the world. Results are published in both non-NASA channels and by NASA in the NASA STI Report Series, which includes the following report types:

- TECHNICAL PUBLICATION. Reports of completed research or a major significant phase of research that present the results of NASA programs and include extensive data or theoretical analysis. Includes compilations of significant scientific and technical data and information deemed to be of continuing reference value. NASA counterpart of peer-reviewed formal professional papers but has less stringent limitations on manuscript length and extent of graphic presentations.

- TECHNICAL MEMORANDUM. Scientific and technical findings that are preliminary or of specialized interest, e.g., quick release reports, working papers, and bibliographies that contain minimal annotation. Does not contain extensive analysis.

- CONTRACTOR REPORT. Scientific and technical findings by NASA-sponsored contractors and grantees.
- CONFERENCE PUBLICATION. Collected papers from scientific and technical conferences, symposia, seminars, or other meetings sponsored or cosponsored by NASA.

- SPECIAL PUBLICATION. Scientific, technical, or historical information from NASA programs, projects, and missions, often concerned with subjects having substantial public interest.

- TECHNICAL TRANSLATION. Englishlanguage translations of foreign scientific and technical material pertinent to NASA's mission.

Specialized services also include creating custom thesauri, building customized databases, organizing and publishing research results.

For more information about the NASA STI program, see the following:

- Access the NASA STI program home page at http://www.sti.nasa.gov

- E-mail your question via the Internet to help@ sti.nasa.gov

- Fax your question to the NASA STI Help Desk at $443-757-5803$

- Telephone the NASA STI Help Desk at 443-757-5802

- Write to: NASA Center for AeroSpace Information (CASI) 7115 Standard Drive Hanover, MD 21076-1320 


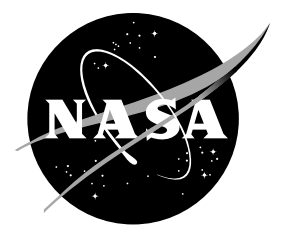

\section{Stiffness and Damping Coefficient Estimation of Compliant Surface Gas Bearings for Oil-Free Turbomachinery}

Christopher DellaCorte

Glenn Research Center, Cleveland, Ohio

Prepared for the

International Joint Tribology Conference

cosponsored by the STLE and ASME

San Francisco, California, October 17-20, 2010

National Aeronautics and

Space Administration

Glenn Research Center

Cleveland, Ohio 44135 


\section{Acknowledgments}

The author wishes to acknowledge the support of NASA's Subsonic Rotary Wing Project for providing the resources necessary to undertake this work.

This report contains preliminary findings, subject to revision as analysis proceeds.

Level of Review: This material has been technically reviewed by technical management.

Available from

NASA Center for Aerospace Information 7115 Standard Drive

Hanover, MD 21076-1320
National Technical Information Service 5301 Shawnee Road Alexandria, VA 22312

Available electronically at http://gltrs.grc.nasa.gov 


\title{
Stiffness and Damping Coefficient Estimation of Compliant Surface Gas Bearings for Oil-Free Turbomachinery
}

\author{
Christopher DellaCorte \\ National Aeronautics and Space Administration \\ Glenn Research Center \\ Cleveland, Ohio 44135
}

\begin{abstract}
Foil gas bearings are a key technology in many commercial and emerging Oil-Free turbomachinery systems. These bearings are non-linear and have been difficult to analytically model in terms of performance characteristics such as load capacity, power loss, stiffness and damping. Previous investigations led to an empirically derived method, a rule-ofthumb, to estimate load capacity. This method has been a valuable tool in system development. The current paper extends this tool concept to include rules for stiffness and damping coefficient estimation. It is expected that these rules will further accelerate the development and deployment of advanced Oil-Free machines operating on foil gas bearings.
\end{abstract}

\section{Nomenclature}

$\begin{array}{ll}\text { ACM } & \text { Air Cycle Machine } \\ \text { APU } & \text { Auxiliary Power Unit } \\ \text { DN } & \text { bearing surface velocity parameter } \\ \text { W } & \text { shaft load, lb } \\ \mathrm{W}_{\mathrm{LC}} & \text { load capacity at speed, lb } \\ C & \text { bearing damping coefficient, lb-sec/in. } \\ C_{o} & \text { area specific damping coefficient, lb-sec/in. }{ }^{3 .} \\ K & \text { bearing stiffness coefficient, lb/in. } \\ K_{o} & \text { area specific stiffness coefficient, lb/in. }{ }^{3} \\ D & \text { bearing performance coefficient }\left(\mathrm{lb} / \mathrm{in}^{3}{ }^{3} / \mathrm{K}_{\mathrm{rpm}}\right) \\ \mathrm{L} & \text { bearing axial length (in.) } \\ \mathrm{D} & \text { shaft diameter (in.) } \\ \mathrm{K}_{\mathrm{rpm}} & \text { shaft speed in thousands of rpm } \\ \text { ROT } & \text { rule-of-thumb } \\ \text { SSME } & \text { Space Shuttle Main Engine }\end{array}$

\section{Introduction}

Foil gas bearings are self-acting hydrodynamic bearings comprised of a series of sheet metal foil layers from which they derive their name. They are compliant bearings that offer high-speed rotor support while accommodating shaft misalignment and distortion often encountered in turbomachinery. Figure 1 shows a cross section of a typical bump-style foil bearing. Lightly loaded, low temperature foil gas bearings are commodities that predominate in the rotor support for aircraft air cycle machines (ACM)'s. More highly loaded foil bearings operating at high temperatures are an emerging technology making commercial inroads into several markets (Ref. 1). These include aircraft auxiliary power units (APU)'s, microturbines, gas compressors and blowers and turbochargers (Refs. 2 and 3). The general trend for foil bearings since their initial development over five decades ago is application to larger and ever more complex rotor systems (Ref. 4). As this proliferation occurs, more practitioners will become actively involved with new machine development using foil bearings. Thus there is a great need for application guidelines to establish the feasibility of proposed rotor systems and to identify existing machines that are good candidates for foil bearing use.

When considering rotor support systems (e.g., bearings, dampers, seals) three key performance parameters come into play: load capacity, bearing stiffness and bearing damping capability (Ref. 5). For conventional rotor support technologies, catalog data, empirical models and computerbased predictive tools exist to provide these three critical inputs to a rotor system designer. To undertake a rotor layout design of a conventional oil-lubricated machine, an engineer simply sketches out the rotor system, adds critical components like turbine and compressor wheels, estimates the shaft loads, and inserts rolling element or hydrodynamic bearings. Then the design's rotordynamic performance is assessed and compared to the expected operating regime. If the system is unstable, bearing placement can be altered, operating speed modified or squeeze film dampers can be added. If the bearing loads, stress on the structural components or shaft orbits are excessive larger bearings can be used (Ref. 6).

Such an iterative, analytical design method, however, is possible only if the bearing performance parameters are well understood and if the general rotor design and layout are similar to those already proven by experience. For foil bearing supported machinery, the development path continues to be less clear.

Foil bearings are non-linear structural elements that combine a hydrodynamic lubrication gas film with a compliant elastic foundation that includes coulomb friction that can be slip-stick in character. Coupling fluid dynamics with structural mechanics has made modeling of foil gas bearings and rotors that rely upon them very challenging and uncertain (Ref. 7). In the past, the development of new machines has often been based on previously fielded machines or relied heavily on hardware intensive make-and-break trial 


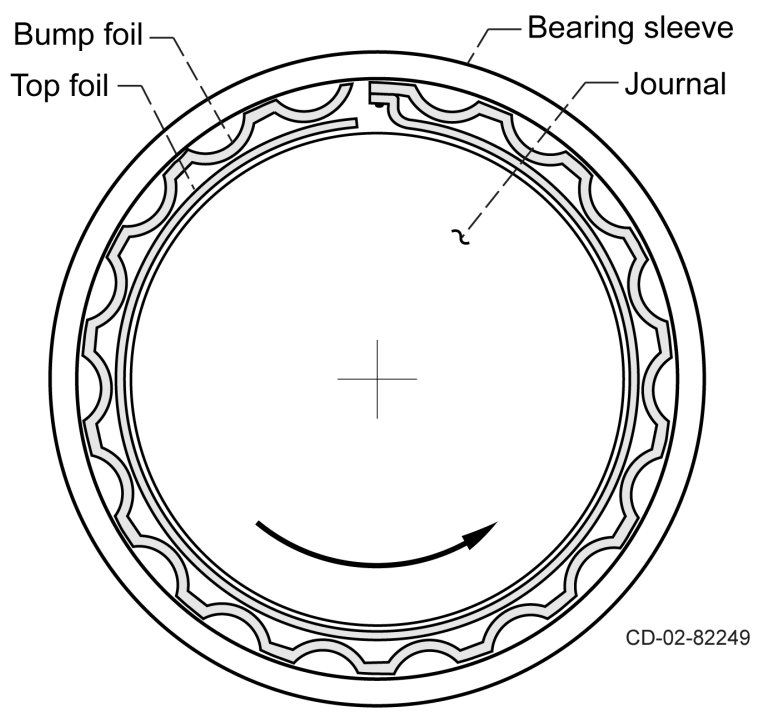

Figure 1.-Cross section sketch of typical foil gas bearing.

and error approaches (Ref. 4). Though these approaches have been successful in spreading foil bearing technology throughout many applications, the lack of more efficient development approaches has hindered the growth of new OilFree systems.

Recently, more methodical step-wise rotor system development techniques have been emerging. Among them is the four-step development process practiced by NASA and industry (Refs. 5 and 8). With this method four distinct sequential and iterative steps are used to carry a machine from initial concept to proven design while minimizing risk and schedule costs. The four-step process consists of: 1) Rotor layout (arrangement) and concept design feasibility assessment; 2) bearing design and performance verification testing; 3) simulated rotor system testing; and 4) turbomachinery system demonstration.

This multi-step approach enables one to tailor the rotor system design to meet an application's specific requirements (power levels, mass flow, pressure ratio, etc.) while staying within the limitations of the rotor support technologies. Since Oil-Free bearing technologies differ significantly in their characteristics compared to conventional bearings, they cannot be directly retrofitted into existing machines without an unacceptable risk of failure (Ref. 9). This design methodology appears clear and straightforward but is somewhat incomplete because methods to estimate basic foil bearing performance parameters are not readily available.

To carry out the first step, one needs to know bearing's load capacity, stiffness behavior and damping capability. The effects of bearing size on these key properties must also be known. Presently, however, only a method to estimate foil bearing load capacity exists (Ref. 7). This load capacity estimation technique was developed by examining experimentally measured load capacity data from numerous foil bearing tests to develop a simple linear algebraic relationship between bearing size, design complexity and operating speed and the resulting load capacity. The ensuing load capacity "rule-of-thumb" (ROT), shown below, has proven effective in guiding new machine development.

Load capacity for a foil gas journal bearing is expressed as a function of load capacity coefficient (D) related to bearing design, bearing length (L), bearing diameter (D), and shaft speed in thousands of revolutions per minute $\left(\mathrm{K}_{\mathrm{rpm}}\right)$ :

$$
\mathrm{W}_{L C}=\boldsymbol{D}(\mathrm{L} * \mathrm{D}) \mathrm{DK}_{\mathrm{rpm}}
$$

Early primitive foil bearings exhibit load capacity coefficients, $\mathcal{D}$, of about $0.3\left(\mathrm{lb} / \mathrm{in}{ }^{3} / \mathrm{K}_{\mathrm{rpm}}\right)$ while more advanced bearings with enhanced structural elastic foundations have coefficients around $1.0\left(\mathrm{lb} / \mathrm{in} .{ }^{3} / \mathrm{K}_{\mathrm{rpm}}\right)$ (Ref. 5). With this model, one can easily size a foil bearing for a particular application.

Methods to estimate critical stiffness and damping parameters, however, do not currently exist. The purpose of this paper is to establish simple tools capable of estimating foil bearing stiffness and damping coefficients suitable for Oil-Free rotor support design work encountered in Step 1 of the four-step development process. This will be accomplished by first coalescing all available empirical data on foil bearing performance which has been generated in the author's own laboratories and by researchers working in university, government and industrial laboratories. All of the data used can be found in the open literature. This information is examined and combined then used to develop ROT for bearing foil bearing stiffness and damping. These ROT's can then be combined with existing rules for load capacity to obtain credible feasibility assessments for proposed Oil-Free rotor systems.

\section{Bearing Dynamic Data Background}

The body of experimental data encompassing foil bearing stiffness and damping behavior is relatively new. Unlike other bearing performance parameters like load capacity, the importance of assessing dynamic properties has only surfaced as an important topic in the last two decades. Gas pipeline compressors used in the petrochemical industry were among the first fields to encounter and address rotordynamic instability issues. Previously, such rotating machines were based upon proven heritage designs and utilized oil-lubricated bearings with ample margins for load capacity and damping while providing adequate stiffness levels for good rotor orbit control. This situation began to change as operators sought to upgrade existing machines to higher speeds and power levels without addressing the rotor support systems (bearings). Consequently failures began to appear resulting in the development of tools to analyze and explain the dynamic phenomena observed in the field (Refs. 10 and 11).

Additional development impetus was derived from the space industry that experienced challenging rotordynamic 
development issues when bringing the SSME turbopumps to fruition. These unprecedented high-speed, high power density pumps relied upon rolling element bearings operating in cryogenic liquids that exhibited little fluid film damping to guarantee stable operation (Ref. 11). Like the petrochemical industry, the space industry shared real concerns regarding the poor level of understanding of bearing dynamic behavior and thus investments were made in this field. These investments resulted in improved models, tools and understanding of the role conventional bearings, dampers and seals play in the rotordynamic performance of rotating machinery. Since gas foil bearings are generally confined to use in lightweight, ultra-high-speed rotating machinery and exhibit relatively low stiffness and damping capability compared to oil wetted bearings, they are particularly susceptible to instability effects (Ref. 10).

In the case of conventionally supported rotors, much of the advances made in understanding rotordynamic stability were based upon or furthered by excellent experimental bearing and damper performance data and field experience of operating machines (Ref. 11). For Oil-Free technologies, such deep data sets do not yet readily exist and likely will not be available until the technology proliferates beyond the relatively small number of machines that currently employ foil bearings. For this reason, it is valuable to collect as much existing data as possible regarding foil bearing stiffness and damping behavior from which the ROT's can be developed. This data is reviewed in the following section.

\section{Data Acquisition Technique Review}

Stiffness and damping data found in the literature fall into three general categories: 1) direct measurements made by shaking or impacting bearings under rotation, 2) shaking or impacting non-rotating bearings, and 3) inferring bearing properties based upon the observed dynamic behavior of a rotating system. Among these approaches, each has its advantages and disadvantages as discussed below.

Direct measurement of bearing dynamic behavior is made by applying a well characterized, known force on an operating bearing and observing the resulting bearing and rotor motions. The application of the forces can be one or multi-directional and can be made via the bearing housing or originate from the rotating shaft. The forces can be of short duration, as is the case of a hammer impact, cyclic in nature (e.g., intentional imbalance) or they can be of extended duration as is often the case with dynamic shakers. Such experiments can be carried out at varying operating speeds, loads and even different ambient temperatures depending upon the desired behavior data. Figures 2(a) and (b) schematically show these approaches.

In general, this technique works by comparing the known input forces to the resulting bearing and shaft motions taking into account the appropriate transfer functions dictated by the system's equations of motion. The dynamic coefficients are then extracted by analysis. The advantages of this technique are enhanced control of the excitation forces and an intrinsically good representation of bearing motions that occur in real machines. Further, the measurements yield dynamic coefficients that can be inputted directly in rotordynamic modeling programs without complex or ill-defined adjustments. Disadvantages include complex test configurations and the excitation forces may not properly mimic environmental forces in real machines. It has also been found that test rig dynamics, i.e., structural natural frequencies, can often corrupt or mask the data. Nonetheless, this direct bearing test method has generally been accepted as the most rigorous technique for generating bearing dynamic data.

The second primary technique is similar to the direct method described previously but is applied to static, nonrotating bearings or even partial bearing structural components such as bump foils. Since foil gas bearing behavior is a composite of the physical characteristics of the gas film and the elastic structural foundation the belief is that once the structure is understood, its behavior can simply be combined with that of the fluid-film to generate a whole bearing response. Though the bearing performance appears to be a coupled fluid-structure phenomenon, this separation of variables approach may be a reasonable first step. Further, since the fluid-film alone is amenable to first principles modeling, this technique essentially breaks a complex problem down into two more tractable challenges best taken separately. In many cases, such structural-only measurements are made to provide inputs of structural stiffness for an analysis or validation code. In general, the measurement of the structural response of a non-rotating bearing yields elastic properties (stiffness) that are higher than an operating bearing. The level of damping, however, is similar to that of a full operating bearing because the gas film tends to offer little additional damping. Some of the earliest bearing behavior measurements have been made with this non-rotating bearing technique (Ref. 12).

The last dynamic assessment technique is indirect and accomplished by inference (Refs. 13 and 14). In effect, simplified real shaft systems supported on foil bearings are well instrumented and operated under a variety of conditions to generate system level behavioral data. Operating conditions that may be varied include imbalance level (magnitude) and location, speed, bearing span, size, placement or arrangement, and misalignment level. Rotordynamic modeling is used to represent the rotor system and the bearing performance coefficient inputs to the model are iterated until the model output matches the bearing parameter inputs. In this way, the bearing characteristics are extracted, or rather inferred, from the experimental data. Figure 2(c) shows such a test rig.

The advantage of this approach is that the data is generated from real shaft systems and includes real world effects like multiple bearing interactions. The disadvantage is that the data is only as accurate as the experimental set-up. Such data can easily be corrupted by system level natural frequencies, 


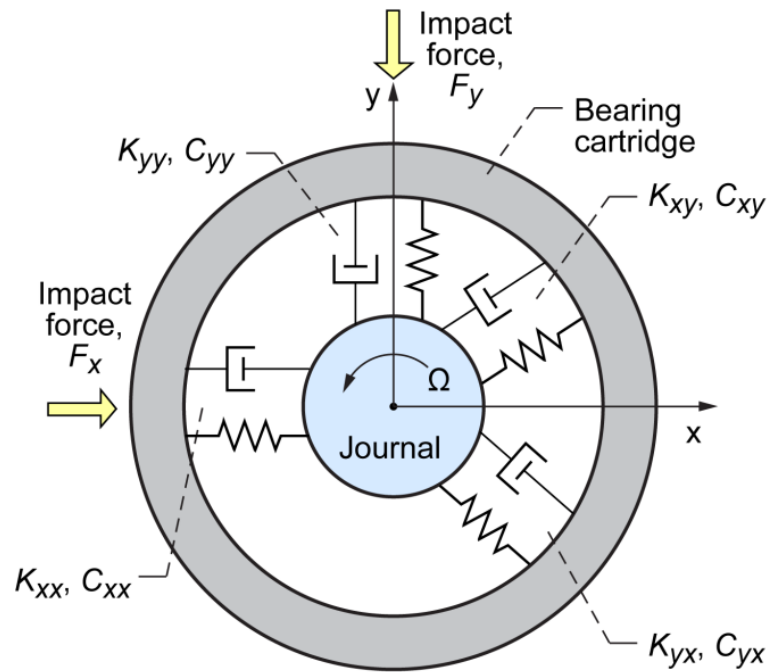

(a)
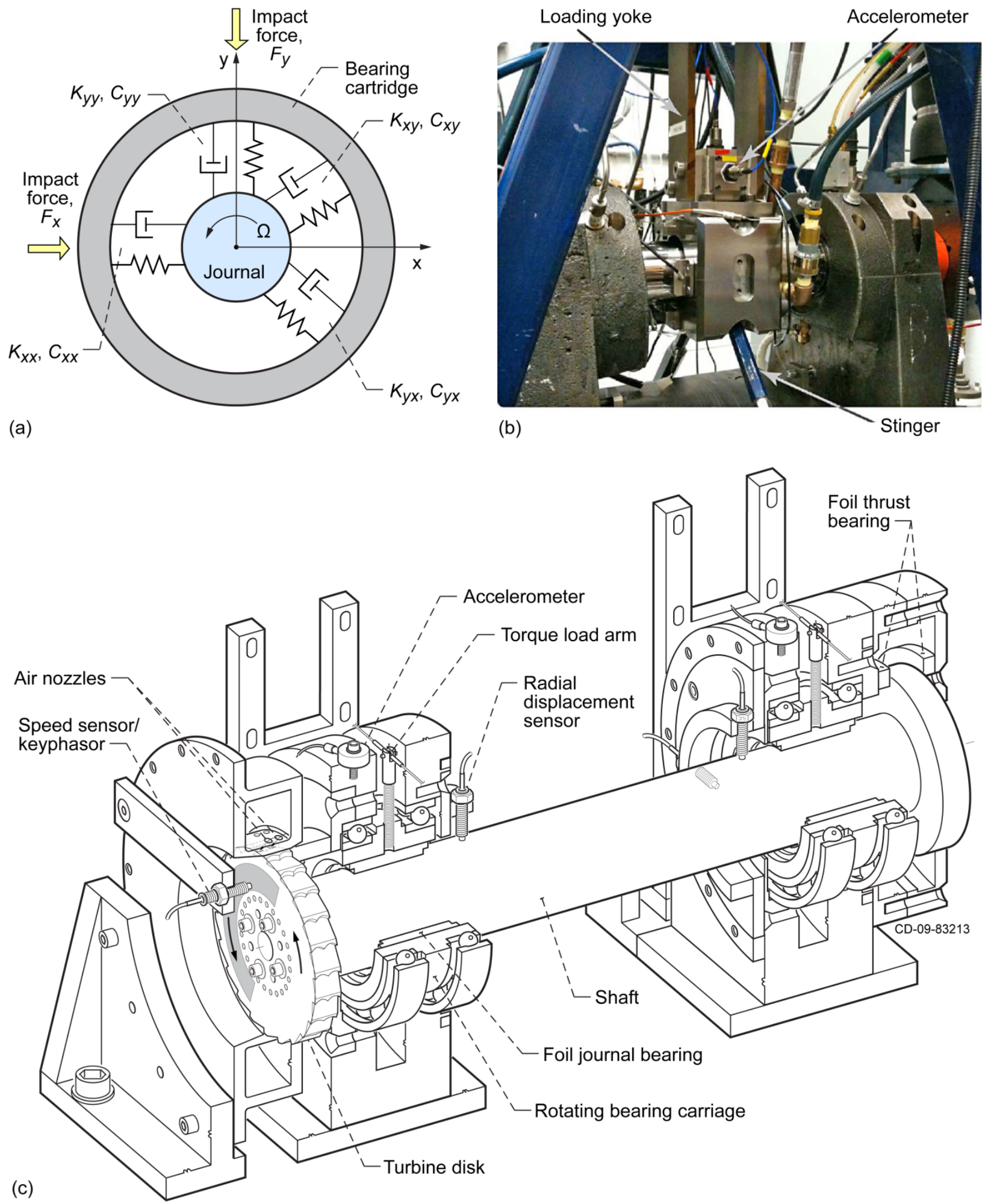

Figure 2.-(a). Test set-up for impact testing from San Andres et al. (Ref. 17). (b). Test set-up for shaking foil bearing to extract coefficients from Conlon et al. (Ref. 19). (c). Rotor rig from which foil bearing coefficients can be inferred from Reference 28. 
manufacturing errors and variations and other factors beyond the control of the experimentalist. In addition, for a given rotor system there may well be several bearing property combinations that yield similar rotordynamic behavior; in other words, the solution may not be unique. This approach also assumes that the model of the rotor system captures all the nuances of foil bearing behavior within the simplified confines of the bearing coefficient inputs. Since the foil bearing is inherently non-linear and is affected by poorly understood phenomena such as coulomb friction and stickslip, such simplified models likely lack sufficient complexity.

Clearly from the above review, no single approach to determine foil bearing performance coefficients is completely credible and without caveats. By combining data from all three approaches and making certain similitude approximations, however, it is hoped that a reasonable cohesive perspective can be developed.

\section{Data Review}

Table 1 represents a comprehensive collection of available foil bearing stiffness and damping performance behavior found in the open literature (Refs. 12 to 24). The table is broken down by the evaluation method used to obtain the bearing performance characteristics based on the three categories described in the previous section. Since bump foil, leaf type foil, wire mesh type foil and cantilevered spring (Capstone) type foil bearings operate under similar principles they are all considered. For general comparison, oil-lubricated tilting pad bearings, gas squeeze film damper-seals and static elastomeric "O-ring" mounts are also included (Refs. 10, 25, and 26).

TABLE 1.--LITERATURE DERIVED STIFFNESS AND DAMPING DATA SUMMARY FOR FOIL BEARINGS

\begin{tabular}{|c|c|c|c|c|c|c|c|}
\hline Test type & Bearing design & $\begin{array}{c}\text { Diameter, } \\
\text { in. }\end{array}$ & $\begin{array}{l}\text { Length, } \\
\text { in. }\end{array}$ & $\begin{array}{c}\text { Stiffness, } \\
\text { K, } \\
\text { lb/in./in. }{ }^{2}\end{array}$ & $\begin{array}{l}\text { Damping, } \\
\text { C, } \\
\text { lb-s/in./in. }{ }^{2}\end{array}$ & $\begin{array}{c}\text { Load } \\
\text { capacity } \\
\text { coefficient, } \\
\mathcal{D} \\
\text { lb/in. }{ }^{3}-\mathrm{K}_{\mathrm{rpm}}\end{array}$ & $\begin{array}{l}\text { Author, } \\
\text { reference no. }\end{array}$ \\
\hline (1) Direct-rotating-impact & Bump Foil-Gen III & 1.4 & 1.1 & 5,000 & 0.8 & $\sim 1.0$ & Howard, (Ref. 15) \\
\hline (1) Direct-rotating-impact & Bump Foil-Gen I & 1.5 & 1.5 & 6,300 & 1.1 & $\sim 0.3$ & Lee et al., (Ref. 16) \\
\hline (1) Direct-rotating-shaker & Bump Foil-Gen I & 2.75 & 2.75 & 2,900 & 5.2 & $\sim 0.3$ & Conlon et al., (Ref. 19) \\
\hline (1) Direct-rotating-shaker & Bump Foil-Gen II & 2.75 & 2.75 & 3,300 & 6.6 & $\sim 0.5$ & Conlon et al., (Ref. 19) \\
\hline (1) Direct-rotating-shaker & Bump Foil-Gen I & 1.50 & 1.50 & 10,000 & 0.9 & $\sim 0.3$ & Rudloffe et al., (Ref. 20) \\
\hline (1) Direct-rotating-shaker & Bump Foil-Gen I & 2.40 & 2.40 & 6,200 & 1.3 & $\sim 0.3$ & Lee et al., (Ref. 21) \\
\hline (1) Direct-rotating-shaker & Bump-Visco-Foil-Gen I & 1.4 & 1.4 & 7,000 & 5.6 & $\sim 0.3$ & Lee et al., (Ref. 22) \\
\hline (3) Inferred-rotor response & Bump Foil Gen III & 2.0 & 2.0 & 5,000 (est.) & 20 & $\sim 1.0$ & Salehi et al., (Ref. 14) \\
\hline Other-test-model & Oil-Lubricated Tilt-Pad & 4.0 & 3.0 & $\sim 100,000$ & $\sim 160$ & $\sim 10.0$ & Leader et al., (Ref. 25) \\
\hline Other-test-model & Elastomeric O-ring support & 0.4 & 0.2 & $\sim 100,000$ & $\sim 12.5$ & N/A & Vance, (Ref. 10) \\
\hline Other-test-model & Gas Squeeze-film damper & 5.0 & 1.25 & -90 & $\sim 0.2$ & N/A & Li et al., (Ref. 26) \\
\hline
\end{tabular}

Notes: Bearing design generation designation (I, II, III) described fully in Reference 7.

Stiffness and damping coefficients are steady-state direct terms $\left(K_{x x}, K_{y y}, C_{x x}, C_{y y}\right)$

Cross-coupled terms $\left(K_{y x}, K_{x y}, C_{y x}, C_{x y}\right)$ generally one order of magnitude or more less than their direct counterparts.

The performance characteristics are simplified for convenience. Only one-dimensional direct stiffness $\left(K_{x x}=K_{y y}\right)$ and direct damping $\left(C_{x x}=C_{x y}\right)$ is considered. Cross-coupled stiffness $\left(K_{y x}, K_{x y}\right)$ and damping coefficients $\left(C_{y x}, C_{x y}\right)$ are assumed to be approximately one order of magnitude less than their direct counterparts, which is typical for compliant surface type hydrodynamic bearings (Refs. 18 to 20 ). The bearing load capacity coefficient $(\boldsymbol{D})$ is also given since it along with the stiffness and damping coefficients form the backbone of any rotordynamic design and layout trade study. In most instances, the load capacity coefficient is measured alongside the dynamic coefficients. If not directly measured it can be estimated based upon the bearing design using the methods outlined in Reference 7. To obtain correlation with bearing geometry, the bearing's performance characteristic has been normalized by its bearing's projected area $\left(\mathrm{L}^{*} \mathrm{D}\right)$.

The data presented is an approximate average from the original references taken at operating frequencies representative of typical bearing applications. The reader is encouraged to refer to the original works for further information. These simplifications and assumptions are justified on the basis that the current work seeks to effectively 
combine a disparate data set. In addition, the goal of the work is not to develop a precise performance predictive tool, but rather, to generate a conservative estimation method with which initial feasibility of a design can be determined. Such an approach was used in developing the ROT for foil bearing load capacity and this technique has been well accepted by the technical community.

\section{Data Discussion}

Upon scrutinizing the data presented in Table 1, the reader may notice that many of the referenced entries are recent publications and that the earliest entries date back just a few decades even though the technology has been in use since the 1960s. This fact belies the recent interest in applying foil bearings to ever larger, higher temperature and higher speed rotor systems without undergoing expensive trial and error hardware intensive efforts. The emphasis on measuring bearing coefficients is also driven by the development of more refined rotordynamic predictive tools that can incorporate complex bearing coefficient matrices in their calculations. Unfortunately, predictive model complexity has far outpaced the ability of the technical community to accurately measure dynamic bearing properties over a wide range of loads, shaft speeds, excitation frequencies and temperatures (Ref. 27). Taken in its entirety, the challenges can appear insurmountable.

For instance, Conlon describes a complicated bearing test rig capable of exciting large foil bearings over a wide range of loads and amplitudes, and frequencies at varying shaft speeds (Ref. 19). Though carefully designed and implemented, the data from the rig appears to be confounded at excitation frequencies above $150 \mathrm{~Hz}$. Other researchers have experienced similar experimental limitations. Howard, for example, carefully modeled his test rig to be able to eliminate the rig structural frequencies and shaft orbit variations from his data (Ref. 15). Moore and Lubell's test rig is limited to synchronous shaft excitation forcing functions at rather unsteady declining frequencies (Ref. 18). Such experimental complications are not considered criticisms of the research. Quite the contrary, these researchers are to be commended for undertaking such a daunting challenge as measuring foil bearing performance coefficients. Nonetheless, these challenges highlight the uncertain and non-linear nature of such measurements.

When one examines the data references in detail it seems that several researchers report a decline in bearing direct stiffness as a function of excitation frequency (Refs. 12, 14, 18, and 19). In some cases, by as much as an order of magnitude has been reported. It is unclear as to the physical reason for this behavior but may be due to the stick-slip, nonlinear response of the foil structure that develops during high frequency displacements. It could also be that this apparent phenomenon is an artifact of the interrogation. For this reason it seems reasonable to also consider the bearing performance coefficients inferred from real machine level experience. When combined with the more direct bearing measurements a clearer picture emerges.

For those data entries that represent the interrogation of non-rotating bearings the reader may notice that stiffness and damping levels tend to be higher than those measured for rotating bearings (Refs. 12 and 23). This is not an unexpected result. In a rotating system, the shaft is separated from the bearing by two springs, the gas film and the elastic foil structure. These springs are in series and thus the softer of the two springs dominates the overall bearing stiffness. For a lightly loaded bearing operating on a relatively thick gas film, the stiffness will be dominated by the soft gas film. For a highly loaded bearing, the gas film is thin and stiff and thus the elastic foundation (structural stiffness) will dominate. For this reason, specifying a single value for bearing (steady state direct) stiffness is difficult and may be misleading. On the other hand, examination of measured data has shown that such stiffness values, when normalized by the bearing size (projected bearing area, $\mathrm{L}^{*} \mathrm{D}$ ) falls within a remarkably narrow range. When one understands that, at the system level, rotordynamic performance is a rather loose function of the bearing stiffness, the assignment of a single value or a narrow range of values for stiffness is more rational.

Based upon these considerations, the following ROT model for foil bearing direct (steady-state) stiffness is offered:

$$
K=K_{o}\left(\mathrm{~L}^{*} \mathrm{D}\right) \mathrm{lb} / \text { in. }^{3}
$$

Where $K_{o}$ is the stiffness coefficient and is taken as between 2,500 and 7,500 with a typical value of 5,000. This stiffness coefficient represents air lubricated foil bearings operating at nominally atmospheric bearing cavity pressure. Foil bearings operating with denser and more viscous fluids, such as oil, water or liquid cryogens or highly pressurized gases will offer commensurately higher stiffness coefficient values, $K_{o}$. Further, lightly loaded bearings will tend to be closer to the softer $(2,500)$ value and heavily loaded bearings will tend to the higher stiffness value $(7,500)$.

The load referred to here is the total bearing load. The total bearing load is comprised of static or deadweight load, dynamic loads caused by shaft unbalance or external effects such as machine motions, fluid and electrical forces, bearing spring preload (interference fit), loads due to bearing misalignment and loads arising from thermal and centrifugal expansion of the shaft. A deeper discussion of the bearing total load can be found in Reference 28. Since it is the total load that effects bearing behavior, a design trade can be made between factors such a load capacity margin and spring preload to tailor bearing properties and thus system rotordynamic response. Oftentimes, this trade involves increasing spring preload to increase bearing stiffness in order to reduce shaft orbit and improve stability (damping typically increases with load). Care must be exercised, however, that the total load remains well below the bearing load capacity at all speeds and conditions otherwise failure can occur. 
The stiffness model expressed above can also be used to conduct a rotordynamic analysis of an existing machine or a candidate rotor design (Ref. 29). By conducting repeated analyses using a range of stiffness $(2,500$ to 7,500$)$ and bearing sizes one can determine the effect bearing stiffness has on critical speeds, shaft orbits, bearing loads, stability and the general reasonableness of the design.

Although not part of the current ROT modeling, crosscoupled stiffness terms, $K_{x y}$ and $K_{y x}$, were also examined. Due to the foil bearing's compliant nature, the cross-coupled stiffness values, when measured and reported are usually very low and often an order of magnitude less than the direct stiffness terms. Because of their low values, cross-coupled effects are less significant for preliminary rotordynamic modeling activities. More rigorous examination can be made during detailed system design.

Interestingly, much of the data in Table 1 falls into the proposed ROT range. Those data entries that are outliers can be understood through deeper examination. For instance, the low stiffness value reported by San Andres (Ref. 17) is for a foil bearing with a metal mesh elastic foundation. Due to the nature of the design, this bearing operates with a fixed and positive clearance even at rest. This is in contrast to traditional foil bearings that are spring preloaded. This clearance or dead band undoubtedly leads to a lower than average bearing stiffness. The high stiffness value reported by Heshmat (Ref. 12) is for a stationary bearing and represents the relatively stiff foil structure as explained previously.

It is also valuable to highlight the high stiffness provided by traditional oil-lubricated bearings (Ref. 25). Such bearings, using highly incompressible oil fluid films, yield stiffness coefficients on the order of 100,000, a full 20 times greater than foil gas bearings. O-rings have comparable stiffness to conventional bearings, $\sim 100,000 \mathrm{lb} / \mathrm{in}_{\text {. }} \mathrm{in}^{2}$, but often have a very small length to diameter ratios yielding limited stiffness values unless many are stacked together in a side-by-side arrangement (Ref. 10). Furthermore, elastomeric O-rings have a tendency to dimensionally relax over time and under load and this can result in detrimental changes to the effective bearing properties and rotordynamic system stability.

Gas lubricated squeeze film dampers, on the other hand have been observed to generate modest, but negative, direct stiffness (Ref. 26). For a marginally stable rotor system such an effect can be undesirable despite the modest but positive damping they tend to provide. It is for this reason that some practitioners have devised ways to use foil bearings as a sealing device (Ref. 30). In this instance they provide positive stiffness and damping to a shaft system.

In terms of establishing a damping ROT model, an examination of the damping coefficient data in Table 1 reveal a picture that is analogous to the stiffness behavior. Much of the damping data, when normalized for bearing size, falls into a fairly narrow range between 0.1 and $10 \mathrm{lb}$-sec/in./in. ${ }^{2}$ with a preponderance of values clustered near $1.0 \mathrm{lb}$-sec/in./in. ${ }^{2}$. Again, one can gain additional insight by more closely scrutinizing that data that differs significantly from average.
Conlon (Ref. 19) reports damping values for large first and second generation bump foil bearings near $5.0 \mathrm{lb}$-sec/in./in. . Such values seem rather high and may be an artifact of his newly developed test rig or test protocol. It may also be that simply extrapolating bearing damping based upon projected area $\left(L^{*} \mathrm{D}\right)$ is inadequate especially for such large $(70$ - by 70 $\mathrm{mm}$ ) bearings. In any case, the values he reports are within the range ( 0.1 to 10$)$ suggested above.

Lee (Ref. 22) also reports rather high damping coefficients $\left(\sim 5.0 \mathrm{lb}\right.$-sec/in./in. $\left.{ }^{2}\right)$ for a bearing tested in his rig that is much smaller than those evaluated by Conlon (Ref. 19). This bearing, however, includes an elastomeric layer in its structural foundation. Given the high damping effect imparted by elastomeric materials the level of this reported value is not surprising.

Heshmat reports high damping values in two instances. The first being for a non-rotating bearing (Ref. 12). For the reasons discussed for bearing stiffness, high values for damping are to be expected since the coupling of the shaft motion to the foil structure is not inhibited nor attenuated by an intermediate gas film. On the other hand, Heshmat (Ref. 14) also reports large damping coefficients $\left(20 \mathrm{lb}-\mathrm{sec} / \mathrm{in} . /\right.$ in. $\left.^{2}\right)$ for rotating bearings. In this test, the bearings had been highly optimized to impart damping to the rotor in order to successfully cross the bending critical speed. Such a test shows that stiffness and damping can be tailored though it is not clear what effects that might have on other bearing properties. Furthermore, the damping reported was inferred from models of the test rig. Heshmat's damping values are similar to those reported by Conlon for large bearings. Further corroboration may be of value.

Damping coefficient measurement has proven to be a difficult task particularly when testing is done in a transient manner. In the future, well controlled, steady state experiments in which mechanical energy dissipated in a bearing could be compared to heat generated in a bearing may be needed to clarify the matter. For instance, a test could be done in which a bearing is continuously shaken with a known and constant amount of energy in a rig in which energy dissipation could be measured, in a calorimetric fashion, to determine if the bearing is actually converting external vibratory work into heat, the presumed dissipation mechanism. Until such an experiment can be conducted, damping coefficient data must be viewed with a degree of uncertainty.

When comparing the nominal damping coefficient value $\left(\sim 1.0 \mathrm{lb}\right.$-sec/in./in. $\left.{ }^{2}\right)$ for foil bearings to other technologies some additional interesting revelations come to light. The damping coefficient for an oil-lubricated tilt-pad bearing is over 150 times that for gas lubricated foil bearings. Elastomeric O-ring mounts provide over ten times the damping of a foil bearing. Given this performance gap it should come as little surprise that foil bearings rarely retrofit into existing machines designed to operate on more traditional bearings. On the other hand, foil bearings compare favorably on a damping basis with purpose built gas squeeze-film dampers. This is also of little surprise since both foil bearings and gas squeeze film dampers utilize gas viscosity for 
damping. Foil bearings, however, further benefit from coulomb friction damping effects originating in the bearing structure (between contacting foil surfaces).

Given the above discussion regarding damping, the following ROT is offered:

$$
C=C_{o}(\mathrm{~L} * \mathrm{D}) \mathrm{lb}-\mathrm{sec} / \mathrm{in}^{3}
$$

where $C_{\mathrm{o}}$ is taken as $\sim 1.0$ with a nominal range of 0.1 to 10.0 depending upon bearing design and operating conditions. Like stiffness, the data also shows that cross-coupled damping terms are much less than the direct damping terms by about an order of magnitude. For most applications these can be ignored during preliminary modeling activities. In follow on design work, commercially available bearing design tools can provide cross-coupled terms for consideration.

The data further suggests, that like stiffness, the damping is related to bearing load. Lightly loaded bearings tend to offer lower damping values while heavily loaded bearings tend to higher damping values. In some applications, this characteristic has been employed to optimize rotor behavior by increasing bearing spring preload thus increasing stiffness and damping. This approach can be detrimental, however, in that bearing load capacity degrades and overload failures can result.

\section{ROT Example: Oil-Free Turbocharger}

To illustrate how the stiffness, damping and load capacity ROT's can be applied, an Oil-Free turbocharger rotor system is examined. The turbocharger modeled is based upon a production machine that originally utilized oil-lubricated floating-sleeve bearings. The project goal was to replace the central bearing housing and replace it with a new housing that incorporated foil bearings.

Howard (Ref. 31) describes a finite element based rotordynamics design trade study he conducted on this turbocharger to arrive at a reasonable machine layout and to establish preliminary bearing sizes. In his paper, he made assumptions about foil bearing performance parameters based upon input from the literature and from the foil bearing manufacturer. He described two possible rotor sizes, short and long, and examined the bearing stiffness dependent critical speeds and overall stability threshold levels. The pertinent system input data is presented in Table 2. Figure 3 shows sketches of the rotors modeled in the paper.
Howard found that while both the short and long rotor configurations were feasible, the long rotor offered more margin on load capacity especially with respect to shock loads. The following uses the ROT's for load capacity, stiffness and damping to assess the short and long rotors analyzed by Howard.

\section{Stiffness}

$$
\begin{aligned}
K & =K_{\mathrm{o}}(\mathrm{L} * \mathrm{D}) \mathrm{lb} / \text { in. }^{3} \\
& =5,000(1.0 * 1.0)=5,000 \mathrm{lb} / \text { in. (short rotor) } \\
& =5,000(1.5 * 1.5)=11,250 \mathrm{lb} / \text { in. (long rotor) }
\end{aligned}
$$

\section{Damping}

$$
\begin{aligned}
C & =C_{o}(\mathrm{~L} * \mathrm{D}) \mathrm{lb}-\mathrm{sec} / \mathrm{in}^{3}{ }^{3} \\
& =1.0(1.0 * 1.0)=1.0 \mathrm{lb} \text {-sec/in. (short rotor) } \\
& =1.0(1.5 * 1.5)=2.25 \mathrm{lb}-\mathrm{sec} / \text { in. (long rotor) }
\end{aligned}
$$

\section{Load Capacity (at idle speed, 20,000 rpm)}

$$
\begin{aligned}
\mathrm{W}_{L C} & =\mathcal{D}(\mathrm{L} * \mathrm{D}) \mathrm{DK}_{\mathrm{rpm}} \\
& =1.0(1.0 * 1.0) 1.0 * 20 \mathrm{~K}_{\mathrm{rpm}} \\
& =20 \mathrm{lb} \text { (short rotor) } \\
& =1.0(1.5 * 1.5) 1.5 * 20 \mathrm{~K}_{\mathrm{rpm}} \\
& =67.5 \mathrm{lb} \text { (long rotor })
\end{aligned}
$$

Based upon the design considerations given in Howard's paper and the bearing requirements shown in Table 2, both the long and short rotor configurations appear feasible with respect to bearing stiffness. The short rotor has no critical speeds in the operating range for bearing stiffness between 1,000 and $12,000 \mathrm{lb} / \mathrm{in}$. while the long rotor avoids critical speeds for stiffness between 1,000 and 18,000 lb/in. When required damping is considered, the outlook is less favorable. Howard's analysis showed that the short rotor requires $1.8 \mathrm{lb}$-sec/in. and the long rotor requires $2.75 \mathrm{lb}-\mathrm{sec} / \mathrm{in}$. but the foil bearing ROT model yields only 1.0 and $2.3 \mathrm{lb}$-sec./in., respectively. Thus it appears that both designs provide insufficient damping though the long rotor is close to being

TABLE 2.--ROTOR GEOMETRY AND BEARING COEFFICIENT REQUIREMENTS FOR OIL-FREE TURBOCHARGER

\begin{tabular}{|c|c|c|c|c|c|c|c|}
\hline $\begin{array}{c}\text { Bearing } \\
\text { diameter, } \\
\text { in. }\end{array}$ & $\begin{array}{c}\text { Bearing } \\
\text { length, } \\
\text { in. }\end{array}$ & $\begin{array}{c}\text { Load } \\
\text { capacity } \\
\text { coefficient, } \\
\text { lb/in. }{ }^{3}\end{array}$ & $\begin{array}{c}\text { Direct } \\
\text { stiffness } \\
\text { required, } \\
\text { lb/in. }\end{array}$ & $\begin{array}{c}\text { Direct } \\
\text { damping } \\
\text { required, } \\
\text { lb-sec/in. }\end{array}$ & $\begin{array}{c}\text { Rotor mass, } \\
\text { lb }\end{array}$ & $\begin{array}{c}\text { Load per } \\
\text { bearing }\end{array}$ & Comments \\
\hline 1.0 & 1.0 & 1.0 & $1-12,000$ & $>1.8$ & 3.0 & 1.5 & Short rotor \\
\hline 1.5 & 1.5 & 1.0 & $1-18,000$ & $>2.75$ & 4.0 & 2.0 & Long rotor \\
\hline 1.38 & 1.06 & 1.0 & TBD & TBD & 3.7 & 1.85 & As built \\
\hline
\end{tabular}

Notes: To be determined (TBD).

Bearing requirements derived from finite element based rotordynamics modeling (Ref. 30) 

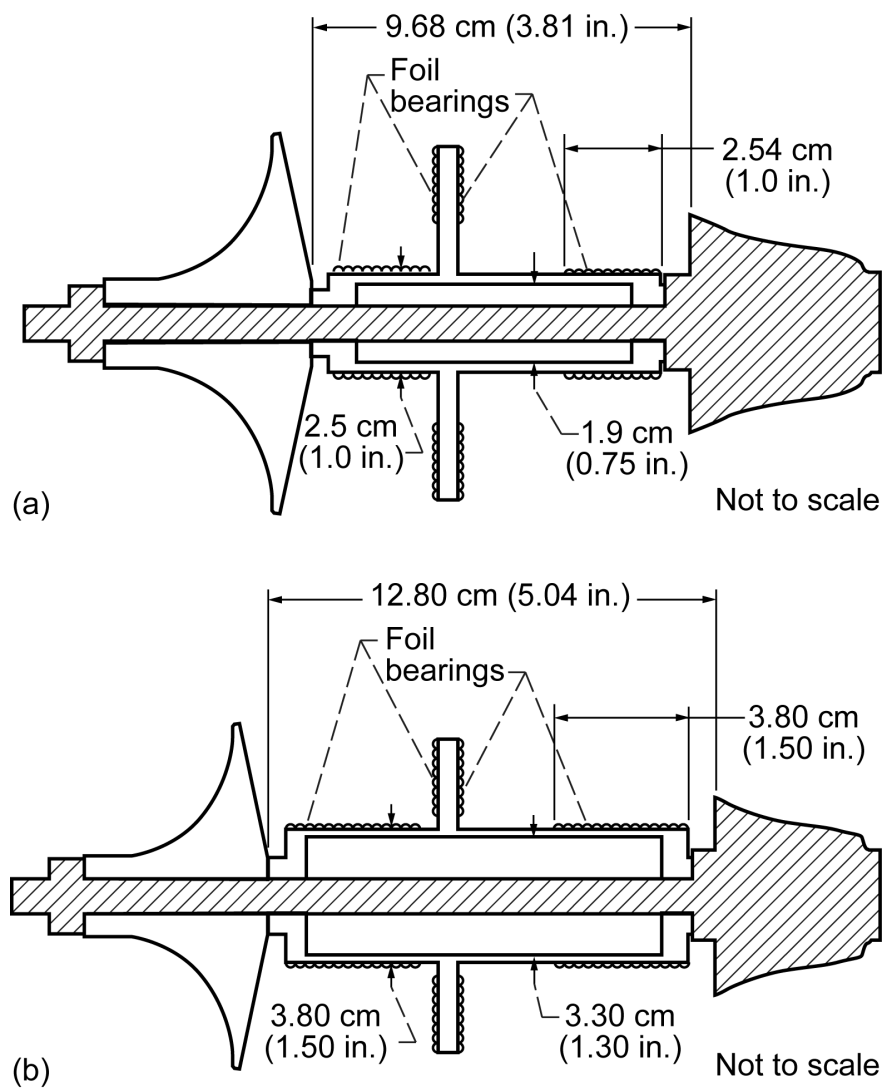

Figure 3.-Turbocharger models from Reference 31.

(a) Short rotor oil-free (b). Long rotor oil-free.

acceptable. The last major parameter to be assessed using the ROT models is load capacity.

For most turbomachines supported on foil bearings, shock loads that occur at low rotor speeds are the most challenging. This is because foil bearing load capacity is directly related to rotor speed. At high speed most Oil-Free machines have excess load capacity. In fact it is just this phenomenon (lightly loaded high speed bearing operation) that can lead to rotordynamic instability. For the turbocharger rotors under consideration, comparing shock load levels to the load capacity at idle speed assesses load capability. At an idle speed of $20,000 \mathrm{rpm}$, the short and long rotors have load capacities of 20 and $67.5 \mathrm{lb}$ while $10 \mathrm{~g}$ shock loads are 15 and $20 \mathrm{lb}$ and $20 \mathrm{~g}$ shock loads are 40 and $30 \mathrm{lb}$ respectively. From this perspective, the short rotor is marginal on load capacity for a $10 \mathrm{~g}$ shock and will experience a rub under a $20 \mathrm{~g}$ shock load. The long rotor has acceptable load capacity design margins at both shock levels. An additional design consideration is rotor orbit during a high load event (shock load). Adequate clearances between rotating and non-rotating components within the machine must be provided to prevent contact during a load induced rotor orbit excursion. This can be estimated by dividing the shock load by the direct bearing stiffness. For the short rotor a $10 \mathrm{~g}$ shock event will result in a 0.003 -in. radial shaft excursion while the long rotor would experience a 0.002 -in. radial excursion. Designing a turbocharger to accommodate such modest orbit changes is easily achieved since conventional turbochargers operate with more generous clearances.

Given the above considerations the long rotor design appears more robust though damping levels appear inadequate and are marginal at best. Thus it would be wise to revisit the rotor design and the bearing design to try to achieve a better balance between rotor requirements and bearing capabilities.

Interestingly, the modeled turbocharger design was refined and a turbocharger demonstration project was undertaken and reported (Ref. 32). Figure 4 shows this turbocharger along with a sketch of its cross-section. In its final incarnation, the turbocharger dimensions, given in Table 2 , are $\mathrm{D}=1.38 \mathrm{in}$., $\mathrm{L}=1.06 \mathrm{in}$. with a rotor mass of $3.7 \mathrm{lb}$. The selected bearing size is between that considered in the short and long rotor. This design appears adequate for stiffness and load capacity but, like the other designs, may be marginal on damping. To address the stability and damping concerns the final turbocharger bearing design included several novel features to enhance damping and improve the system rotordynamics (Ref. 32).

The foil bearing elastic structure was tailored to improve damping levels and to shift the bearing hydrodynamic center of pressure outboard effectively lengthening the shaft in terms of rotordynamic behavior (Ref. 33). In addition, the bearing was more heavily spring preloaded to further increase damping and stiffness levels. Increasing bearing loads leads to increased damping and stiffness because the more heavily loaded gas film stiffens and this helps couple the shaft motion to the bearing elastic structure. In effect, a heavily loaded bearing more closely resembles the dynamic behavior of a non-rotating bearing from stiffness and damping point of view. In the case of the Oil-Free turbocharger demonstration, increased spring preload while avoiding bearing overload was possible because the excellent load capacity coefficient $(\boldsymbol{O} \sim 1.0)$ provided satisfactory margins on load capacity (Ref. 34). Several commercial manufacturers are now coming to market with similar machines (Refs. 35 and 36). Based upon the turbocharger example presented, it appears that the foil bearing stiffness, damping and load capacity ROT's offer a reasonable method to conduct preliminary design and feasibility studies leading to successful new Oil-Free machines. 


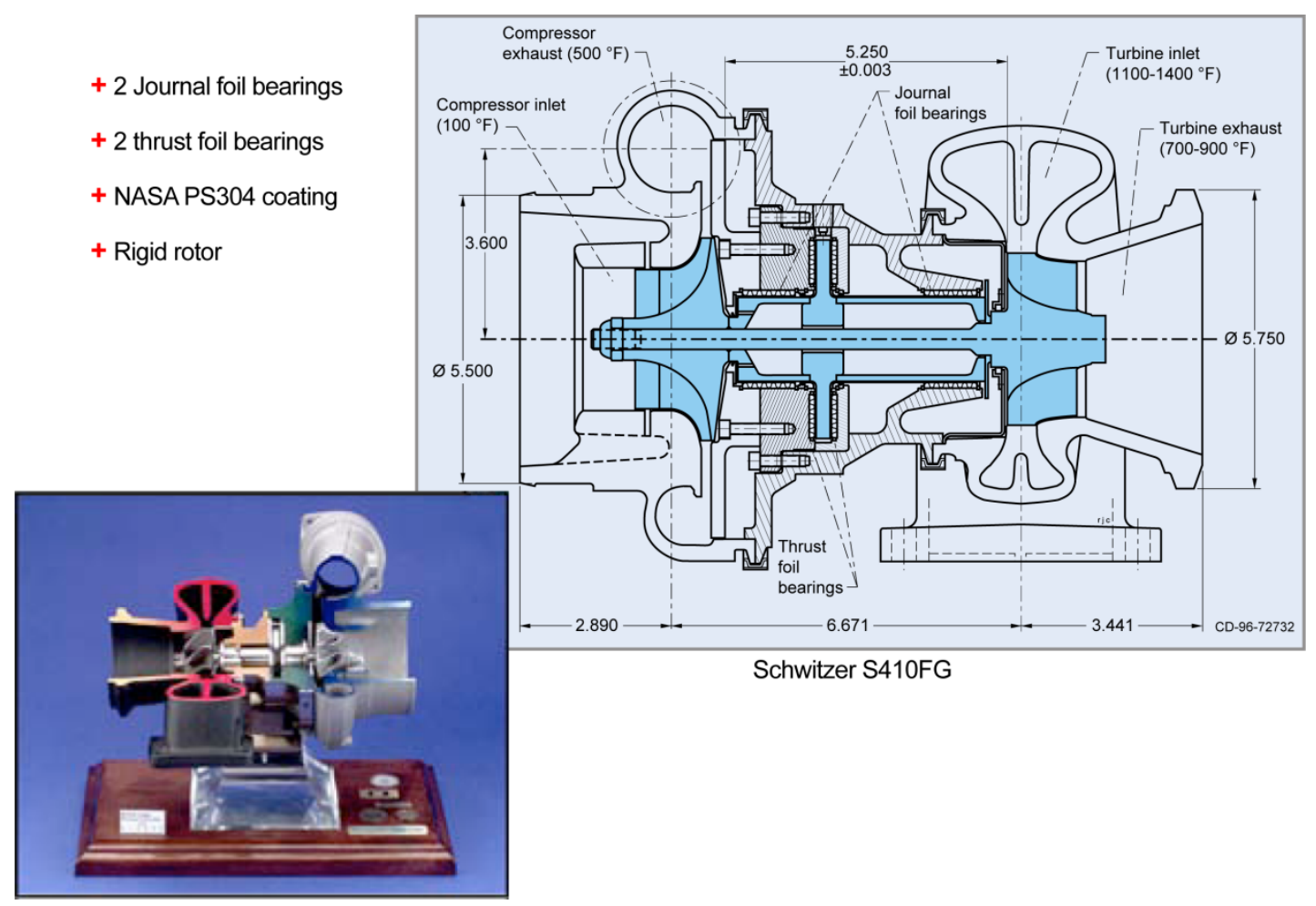

Figure 4.-Oil-free turbocharger.

\section{Summary Remarks}

This paper introduces new rules-of-thumb (ROT) models for foil bearing stiffness and damping coefficient estimation that, when combined with commercial rotordynamic modeling tools and a previously developed ROT for bearing load capacity, can be used to conduct initial rotor design and layout studies. These tools, which are based upon a growing experimental and inferential database, are shown to be effective in helping to determine the feasibility of existing and candidate rotor systems that employ foil gas bearings. It is expected that the availability of such tools will greatly aid and accelerate the deployment of advanced, high-speed machines operating on foil bearings.

\section{References}

1. DellaCorte, C. and Valco, M.J.: "Oil-Free Turbomachinery Technology for Regional Jet, Rotorcraft and Supersonic Business Jet Propulsion Engines," Proceedings of the 2003 ISABE Conference, Cleveland, OH, AIAA/ISABE 2003-1182.

2. Kolanowski, B.F.: Guide to Microturbines, Marcel Dekker, New York, NY, Ch. 1, pp. 1-15, 2004.

3. Lubell, D., DellaCorte, C., and Stanford, M.K.: "Test Evolution and Oil-Free Engine Experience of a High Temperature Foil Air Bearing Coating," Proceedings of GT2006: ASME Turbo Expo 2006, May 8-11, 2006, Barcelona, Spain, GT2006-90572.
4. Klaass, R.F., and DellaCorte, C.: "The Quest for Oil-Free Gas Turbine Engines," Proceedings of the Power Systems Conference, New Orleans, LA, SAE 2006-01-3055, November 2006.

5. DellaCorte, C., and Bruckner, R.J.: "Remaining Technical Challenges and Future Plans for Oil-Free Turbomachinery," Proceedings of 2010 ASME-IGTI Turbo Expo, Glasgow, UK, GT2010-22086, June 2010.

6. Rao, J.S.: Rotor Dynamics, 2nd Edition, Wiley Eastern Limited, New Delhi, India, 1991.

7. DellaCorte, Christopher and Valco, Mark J.: "Load Capacity Estimation of Foil Air Journal Bearings for Oil-Free Turbomachinery Applications," Tribology Transactions, Vol. 43, No. 4, pp. 795-801, October 2000.

8. Howard, S.A.: "Integration Methodology for Oil-Free Shaft Support Systems: Four Steps to Success," Proceedings of the 8th IFToMM International Conference on Rotordynamics, September 12-15, 2010, KIST, Seoul, Korea.

9. Valco, M.J., and DellaCorte, C.: "Emerging Oil-Free Turbomachinery Technology for Military Propulsion and Power Applications," Proceedings of the U.S. Army Sciences Conference, Ft. Lauderdale, FL, February 2003.

10. Vance, J.M.: Rotordynamics of Turbomachinery, John Wiley \& Sons, New York, NY, p. 249, 1988.

11. Childs, D.W.: Turbomachinery Rotordynamics: Phenomena, Modeling and Analysis, John Wiley and Sons, 1993.

12. Heshmat, H., and Ku, C.P.: "Structural Damping of Self-Acting Compliant Foil Journal Bearings," ASME Journal of Tribology, Vol. 116, pp. 76-82, January 1994.

13. Suriano, F.J., 1981, "Gas Foil Bearing Development Program," U.S. Air Force Report Number AFWAL-TR-81-2095 
14. Salehi, M., Heshmat, H., and Walton, J.F.: "On the Frictional Damping Characterization of Compliant Bump Foils," ASME Journal of Tribology, Vol. 125, pp. 804-813, October 2003.

15. Howard, S.A.: "Characterization of the Rotordynamics Properties of Compliant Air Journal Bearings," Ph.D. Dissertation, Case Western Reserve University, May 2000.

16. Lee, Y.B., Park, D.J., Kim, C.H., and Kim, S.J.: "Operating Characteristics of the Bump Foil Journal Bearings with Top Foil Bending Phenomenon and Correlation Among Bump Foils," Tribology International, Vol. 41, Issue 4, pp. 221-233, April 2008.

17. San Andres, L., and Chirathadam, T.A.: "Identification of Rotordynamic Force Coefficients of a Metal Mesh Foil Bearing Using Impact Load Excitations," Proceedings of 2010 ASMEIGTI Turbo Expo, Glasgow, UK, GT2010-22440, June 2010.

18. Moore, J.J., Lerche, A., Allison, T., Ransom, D.L., and Lubell, D.: "Development of a High Speed Gas Bearing Test Rig to Measure Rotordynamic Force Coefficients," Proceedings of 2010 ASME-IGTI Turbo Expo, Glasgow, UK, GT2010-23217, June 2010.

19. Conlon, M.J., Dadouche, A., Dmochowski, W.M., Payette, R. and Bedard, J.P.:"A Comparison of the Steady-State and Dynamic Performance of First and Second Generation Foil Bearings," Proceedings of 2010 ASME-IGTI Turbo Expo, Glasgow, UK, Paper GT2010-23683, June 2010.

20. Rudloff, L., Arghir, M., Bonneaue, O., and Matta, P.: "Experimental Analyses of a First Generation Foil Bearing Startup Torque and Dynamic Coefficients," Proceedings of 2010 ASME-IGTI Turbo Expo, Glasgow, UK, GT2010-22966, June 2010.

21. Lee, Y.B., Kim, T.H., Kim, C.H., Lee, N.S., and Jang, G.H.: "Flexible Rotor Supported by Viscoelastic Foil Bearings Beyond the Bending Critical Speed," Proceedings of the $6^{\text {th }}$ IFToMM Conference on Rotordynamics, Australia, 2, pp. 994-951, 2002.

22. Lee, Y.B., Kim, T.H., Kim, C.H., Lee, N.S., and Choi, D.H.: "Unbalance Response of a Supercritical Rotor Supported by Foil-Bearings-Comparison with Test results," Tribology Transactions, Vol. 47, pp. 54-60, January 2004.

23. Yoshimoto, S., Nagata, K., and Miyatake, M.: "Instability of Herringbone-Grooved Aerodynamic Floating Bush Bearings Flexibly Supported by Foils with Hemispherical Bumps," Proceedings of the 2007 ASME/STLE International Joint Tribology Conference, IJTC2007-44254, October 2007.
24. Strom, T.N.: "Advanced Gas Turbine (AGT) Technology Development Project-Final Report," NASA CR-180891, December 1987.

25. Leader, M.E., Whalen, J.K., Grey, G.G., and Hess, T.D.: "The Design and Application of a Squeeze Film Damper Bearings to a Flexible Steam Turbine Rotor," Proceedings of the 24th Turbomachinery Symposium, September 25-28, 1995, Texas A\&M University, TX, 1995.

26. Li, J., Aguilar, R., San Andres, L., and Vance, J.M.: "Dynamics Force Coefficients of a Multiple-Blade, Multiple Pocket Gas Damper Seal: Test Results and Predictions," ASME/STLE Tribology Conference, 99-TRIB-35, 1999.

27. DellaCorte, C., Radil, K.C., Bruckner, R.J., and Howard, S.A.: "A Preliminary Foil Gas Bearing Performance Map," NASA/TM-2006-214343 and ARL-TR-3902, October 2006.

28. Howard, S.A., and San Andres, L.: "A New Analysis Tool Assessment for Rotordynamic Modeling of Gas Foil Bearings," Proceedings of 2010 ASME-IGTI Turbo Expo, Glasgow, UK, GT2010-22508, June 2010.

29. Chen, W.J., and Gunter, E.J., Introduction to Dynamics of RotorBearing Systems, Trafford Publishing, 2001.

30. Heshmat, H.: "Compliant Foil Seal," U.S. Patent no. 6,505,837, January 2003.

31. Howard, S.A.: "Rotordynamics and Design Methods of an OilFree Turbocharger," NASA/CR_1999-208689, January 1999.

32. Heshmat, H., Walton, J.F., DellaCorte, C., and Valco, M.J.: "OilFree Turbocharger Demonstration Paves Way to Gas Turbine Engine Applications," presented at the International Gas Turbine \& Aeroengine Congress \& Exhibition sponsored by the American Society of Mechanical Engineers, Munich, Germany, May 8-11, 2000, 2000-GT-620.

33. Heshmat, H.: "High Load Capacity Compliant Foil Hydrodynamic Journal Bearing," U.S. Patent no. 5,902,048, May 1999.

34. DellaCorte, C., Valco, M.J., Radil, K.C., Heshmat, H., and Lukaszewicz, V.L.: "Performance and Durability of High Temperature Foil Air Bearings for Oil-Free Turbomachinery," Tribology Transactions, Vol. 43, No. 4, pp. 774-780, October 2000.

35. LaRue, G.D., Kang, S.G. and Wick, W. (2006), "Turbocharger with Hydrodynamic Foil Bearings," U.S. Patent No. 1,108,488.

36. Lee, Y.B., Park, D.J., and Kim, C.H.: "Stability and Efficiency of Oil-Free Turbocharger with Foil Bearings for SUV," SAE 08SFI-0083, 2008. 


\begin{tabular}{|c|c|c|}
\hline \multicolumn{2}{|c|}{ REPORT DOCUMENTATION PAGE } & $\begin{array}{l}\text { Form Approved } \\
\text { OMB No. 0704-0188 }\end{array}$ \\
\hline \multicolumn{3}{|c|}{$\begin{array}{l}\text { The public reporting burden for this collection of information is estimated to average } 1 \text { hour per response, including the time for reviewing instructions, searching existing data sources, gathering and maintaining the } \\
\text { data needed, and completing and reviewing the collection of information. Send comments regarding this burden estimate or any other aspect of this collection of information, including suggestions for reducing this } \\
\text { burden, to Department of Defense, Washington Headquarters Services, Directorate for Information Operations and Reports (07004-0188), 1215 Jefferson Davis Highway, Suite } 1204 \text {, Arlington, VA } 22220-4302 \text {. } \\
\text { Respondents should be aware that notwithstanding any other provision of law, no person shall be subject to any penalty for failing to comply with a collection of information if it does not display a currently valid OMB } \\
\text { control number. } \\
\text { PLEASE DO NOT RETURN YOUR FORM TO THE ABOVE ADDRESS. }\end{array}$} \\
\hline $\begin{array}{l}\text { 1. REPORT DATE (DD-MM-YYYY) } \\
01-12-2010\end{array}$ & $\begin{array}{l}\text { 2. REPORT TYPE } \\
\text { Technical Memorandum }\end{array}$ & 3. DATES COVERED (From - To) \\
\hline \multirow{3}{*}{\multicolumn{2}{|c|}{$\begin{array}{l}\text { 4. TITLE AND SUBTITLE } \\
\text { Stiffness and Damping Coefficient Estimation of Compliant Surface Gas Bearings for Oil- } \\
\text { Free Turbomachinery }\end{array}$}} & 5a. CONTRACT NUMBER \\
\hline & & 5b. GRANT NUMBER \\
\hline & & 5c. PROGRAM ELEMENT NUMBER \\
\hline \multirow{3}{*}{\multicolumn{2}{|c|}{$\begin{array}{l}\text { 6. AUTHOR(S) } \\
\text { DellaCorte, Christopher }\end{array}$}} & 5d. PROJECT NUMBER \\
\hline & & 5e. TASK NUMBER \\
\hline & & $\begin{array}{l}\text { 5f. WORK UNIT NUMBER } \\
\text { WBS 877868.02.07.03.01.01.04 }\end{array}$ \\
\hline \multicolumn{2}{|c|}{$\begin{array}{l}\text { 7. PERFORMING ORGANIZATION NAME(S) AND ADDRESS(ES) } \\
\text { National Aeronautics and Space Administration } \\
\text { John H. Glenn Research Center at Lewis Field } \\
\text { Cleveland, Ohio 44135-3191 }\end{array}$} & $\begin{array}{l}\text { 8. PERFORMING ORGANIZATION } \\
\text { REPORT NUMBER } \\
\text { E-17500 }\end{array}$ \\
\hline \multirow{2}{*}{\multicolumn{2}{|c|}{$\begin{array}{l}\text { 9. SPONSORING/MONITORING AGENCY NAME(S) AND ADDRESS(ES) } \\
\text { National Aeronautics and Space Administration } \\
\text { Washington, DC 20546-0001 }\end{array}$}} & $\begin{array}{l}\text { 10. SPONSORING/MONITOR'S } \\
\text { ACRONYM(S) } \\
\text { NASA }\end{array}$ \\
\hline & & $\begin{array}{l}\text { 11. SPONSORING/MONITORING } \\
\text { REPORT NUMBER } \\
\text { NASA/TM-2010-216924 }\end{array}$ \\
\hline \multicolumn{3}{|c|}{$\begin{array}{l}\text { 12. DISTRIBUTIONIAVAILABILITY STATEMENT } \\
\text { Unclassified-Unlimited } \\
\text { Subject Categories: 07, 20, and } 37 \\
\text { Available electronically at http://gltrs.grc.nasa.gov } \\
\text { This publication is available from the NASA Center for AeroSpace Information, 443-757-5802 }\end{array}$} \\
\hline
\end{tabular}

\section{SUPPLEMENTARY NOTES}

\section{ABSTRACT}

Foil gas bearings are a key technology in many commercial and emerging Oil-Free turbomachinery systems. These bearings are non-linear and have been difficult to analytically model in terms of performance characteristics such as load capacity, power loss, stiffness and damping. Previous investigations led to an empirically derived method, a rule-of-thumb, to estimate load capacity. This method has been a valuable tool in system development. The current paper extends this tool concept to include rules for stiffness and damping coefficient estimation. It is expected that these rules will further accelerate the development and deployment of advanced Oil-Free machines operating on foil gas bearings.

\section{SUBJECT TERMS}

Bearings; Gas bearings; Foil bearings

\begin{tabular}{|c|c|c|c|c|c|}
\hline \multicolumn{3}{|c|}{ 16. SECURITY CLASSIFICATION OF: } & \multirow{2}{*}{$\begin{array}{l}\text { 17. LIMITATION OF } \\
\text { ABSTRACT } \\
\text { UU }\end{array}$} & \multirow{2}{*}{$\begin{array}{l}\text { 18. NUMBER } \\
\text { OF } \\
\text { PAGES } \\
17\end{array}$} & \multirow{2}{*}{$\begin{array}{l}\text { 19a. NAME OF RESPONSIBLE PERSON } \\
\text { STI Help Desk (email:help@sti.nasa.gov) } \\
\text { 19b. TELEPHONE NUMBER (include area code) } \\
\text { 443-757-5802 }\end{array}$} \\
\hline $\begin{array}{l}\text { a. REPORT } \\
U\end{array}$ & $\begin{array}{l}\text { b. ABSTRACT } \\
\mathrm{U}\end{array}$ & $\begin{array}{l}\text { c. THIS } \\
\text { PAGE } \\
\text { U }\end{array}$ & & & \\
\hline
\end{tabular}



